\title{
Prime Minister Suga and His Rejection of Six Nominees: A Study of Speech Styles
}

\author{
Shoji Azuma \\ Department of World Languages and Cultures \\ University of Utah \\ Salt Lake City, Utah 84112 \\ USA
}

\begin{abstract}
The new Prime Minister of Japan, Yoshihide Suga (2020-),recently rejected six academic nominees for the prestigious Science Council of Japan, creating a stir in academic and political circles as well as among the general public. Though funded by the government, the Science Council of Japan makes independent policy recommendations and plays a key role in protecting academic freedoms in Japan. Such refusals are unprecedented during the more than seventy year history of the Council, established in 1949 to chart a new course for a democratic Japan at the end of World War II. Suga has not yet offered an explanation for rejecting sixof the 105 nominees, other than to ensure the "wide and comprehensive" activities of the Council. The present paper argues that the speech orientation of Prime Minister Suga, specifically his tendency to use "report-talk" over "rapport-talk," is important for understanding the controversy, and that Suga would likely improve his connection with his audiences, if he were to use more emotive speech, or "rapporttalk."
\end{abstract}

Keywords: Japan, new prime minister, political scandal, speech orientation

\section{Who is Yoshihide Suga?}

Yoshihide Suga (1948-) is the current Prime Minister of Japan, who began serving in September 2020 when the longest serving Prime Minister Shinzo Abe resigned due to sudden illness. A powerful politician, Suga served in Abe's administration as his Chief Cabinet Secretary from 2012 to 2020, the longest period of service for any Japanese politician in that position, and also acted as the Minister for Internal Affairs and Communications (2006-2007).

When Abe resigned his Prime Minister position in August 2020, Suga declared his candidacy as a member of the ruling Liberal Democratic Party (LDP) and won the election on the $14^{\text {th }}$ of September with $70 \%$ of the vote. Receiving a remarkably high percentage of votes, Suga's successful election also had his own cabinet giving him an approval rating of $66.4 \%$ compared with a disapproval rating of $16.2 \%$, according to the Kyodo News survey (2020). As a result, Suga's entry as Prime Minister onto the Japan political stage started out quite positively, until his sudden rejection of the six nominees for the Science Council of Japan (hereafter SCJ). Unlike his willingness to confront the COVID-19 pandemic and the recovering Japanese economy, Suga's avoidance and handling of the SCJ controversy has raised concerns from a wide array of players in Japanese society. Generally known to be an honest, straightforward, hardworking and sometimes stubborn politician, Suga has surprised his colleagues and the general public with these recent actions.

\section{What is the Science Council of Japan (SCJ)?}

The Science Council of Japan (SCJ) is a representative body of the Japanese academic community and includes disciplines from all the sciences and humanities, ranging from social sciences, life sciences, natural sciences, and engineering. In January 1949, it was established as a "special organization" under the jurisdiction of the Prime Minister, operating independently of the government. Its purpose is to provide scientific and academic deliberation on important and relevant issues of science, helping resolve and explain solutions, and coordinate efficient academic studies among groups. Unlike similar organizations in other countries, the Council is fully funded and supported through annual governmental subsidies of $\$ 9.4$ million (1 billion Japanese yen). The unique arrangement makes it a significant highly-regarded organization for the Japanese people.

\section{What is the controversy?}

Each of the 210 members on the SCJ serves a six year term. Half of them (105), usually nominated by the academic community, are appointed every three years. The six nominees rejected by Prime Minister Suga include professors from respected universities such as Jikei University School of Medicine, Ritsumeikan University, Tokyo University, Kyoto 
University and Waseda University. Seen by many as politically motivated, Suga's rejections are assumed to be related to the support shown by these six scholars for controversial security legislation (passed in 2015 by the then Liberal Democratic Party-led government), which permits Japan to deploy military forces to respond to foreign attacks under certain conditions.

The reaction by the general public as well as scholars and intellectuals was strong and swift. During the first week of October, 2020, protesters marched in front of the Prime Minister's office and outspoken critics warned of an erosion of "democracy" and "freedom" for academia. More than 120,000 people signed a petition in just three days, reflecting the mounting criticism for such actions (University World News, 2020).Kyodo News agency reported that $72 \%$ of the general public considered Prime Minister Suga's explanation for his actions to be unsatisfactory (October 19, 2020).The current president of the SCJ, Takaaki Kajita, a Nobel laureate, spoke out against the Prime Minister's decision, and was joined by a chorus of other scholars and the general public denouncing the choice.

Suga has continued to give "vague" statements in the Diet regarding the reason for his refusal to appoint the six nominees. He insists it is a "personnel" matter (jinjiken), and refuses to elaborate. However, Suga has referred to a report he received from his Deputy Chief Cabinet Secretary, Kazuhiro Sugita, stating that the six nominees would be excluded from the SCJ. Given this fact, Sugita was asked to provide an explanation in the Diet on the context of the report. But the ruling Liberal Democratic Party (LDP) has refused to allow Sugita to speak to the Diet as an unsworn witness. Meanwhile, the Chief Cabinet Secretary, Katsunobu Kato, continues to echo the "personnel matter" response.

Notwithstanding, the media continues to pressure the government for a more detailed answer. The Mainichi Newspaper, a leading national media organization, in its editorial (November 6, 2020), cited Suga's long standing creed for himself to do the "natural thing" for the public. The editorial implies that the "natural thing" for the Diet to do to perform its role is to call Sugita before the Diet to provide an explanation (The Mainichi. 2020). However, a visit by Sugita to the Diet has yet to occur.

Another newspaper, the Nihon Keizai Shinbun, with a leading policy and economics focus, raised concerns about Suga's vague response. The newspaper wrote an article quoting Professor Takehiko Harutaka (political science) of the Tokyo National Graduate Institute for Policy Studies. According to the article, Harutaka suggests that Suga tends to over-use "balance" (baransu) and "vested interests" (kitokukeneki) which are vague and difficult terms for the general public to understand (Nihon Keizai Shinbun 2020).

\section{Political rhetoric and the controversy.}

Except for a few sociolinguistics cases (e.g., Maynard 1994, Feldman 2000, Ikeda 2009), the study of Japanese political rhetoric in the postwar period is quite limited and in need of further exploration. In the present paper, we address the question of how rhetorical usage influences Japan's political landscape. In particular, we will examine political rhetoric in the context of the recent controversy brought about by the new Japanese Prime Minister's decision to reject the six nominee academicians. We will examine Suga's political speech from a sociolinguistic viewpoint, namely a speech style study, and argue that there are both positive(open) and negative (closed) aspects in his talking style. Finally, from a theoretical perspective, we will examine two types of speech styles, namely "report style" and "rapport style" in political speeches, and draw some conclusions.

For the present paper, all conversational samples were taken from video-tapes made by the Parliamentary Minutes Search System (Kokkai Kaigiroku Kensaku). This service has been funded by the Japanese government and it is easily accessible to the general public.

\section{Positive (open) aspects of Suga's speech style}

In the months of October and November, 2020, the Diet committee members and the entire cabinet, including Prime Minister Suga, attended various formal information sessions. One of the pressing topics discussed at these meetings was Suga's rejection of the six nominees from the SCJ. Although the topic was debated at a number of sessions, one committee meeting in particular, on November 2, 2020, sheds light on the issue.

In particular, I will focus on the congressional debate in the meeting between Hiroshi Kawachi of the Constitutional Democratic Party (CDP), an opposing party to the government-led Liberal Democratic Party (LDP), and Prime Minister Suga speaking during the House of Representative Budget Committee Meeting (Shuugin Yosan Iinkai).

One interesting aspect of the meeting is the very polite and courteous speech style used by the opposing party member, Kawachi, while focusing on his questioning of Suga. 
He maintained a friendly demeanor even though he was acting on behalf of the opposition, and this psychological shift in attitude might have had a positive (open) influence on Suga's behavior. Kawachi started his questioning with the very polite and gentle words of

"Sugasouridaijinikakakuryoo no minasanya Kasumigaseki kanryoo no minasanmo, yorosikuonegaishimasu" (Prime Minister Suga and government officials in this room. Thank you for your time and attention). To an ordinary public person, this language may sound reasonable for any meeting, however, in the context of these meetings, it was actually a very polite and docile way to start the session. No opposition committee member has ever begun a committee meeting in this cordial manner, except this time, with Kawachi. The tone of the speech seemed to express psychological and social solidarity between Kawachi and Suga. Let us observe the following actual utterances in Japanese, which were translated into English.

(1). Diet member Kawachi: Soori to shite kangaeru to, Kajitakaichoo o yondekangaeru to, yokuhanashiattemiru to, moo Kajitakaichoowarokumeisuisen shite ne, to kichattandesukara, kiterundesukara, yoobooshowadeteru $n$ desuyo, soori no tokoroni, sore wachotto, jyaahanasu toiukotonishinai to desune, korewa, zuи to tsuzukundesuyo, koochyakujyootaiga, sore wakono korona ka de desu ne, hokanigironshinakerebaikenaikoto moo,taakusanarundesuyo. Soori to shite ketsudan shite kudasai.

(As the Prime Minister, at some time during the rejection process you called in President Kajita and you spoke with him seriously. He's already asked again for you to appoint the six members, as you recall that the request letter for rehiring was clearly issued to you. So you need to speak with him again. Otherwise, this issue will continue without any solution. Specifically, under the pandemic situation, we have so many issues to deal with. I ask you as the Prime Minister to make a concrete and clear decision as soon as possible.)

Notice that Kawachi used frequently the sentence final particles of "yo" and "ne" (tag question). These particles tend not to be part of formal congressional speech because they are typically considered very casual and friendly in Japanese grammar. Thus, Kawachi seems to have expressed a simple and amiable question to solicit solidarity. How did Suga reply to Kawachi's gentle, yet straightforward statement? Was Suga's reply a bureaucratic answer, avoiding any strong commitment, as he has done and usually does in other cases? Let us observe how Suga responded.

(2). Prime Minister Suga: Anoo(pause)rirontekiniwaKawachigiin no iwarerutoori da to omoimasu. De Kajitakaichoogakorarete, kitatokini sorewatashikaniuketorimasita. Ninnmei no yooboushonitsuite. Sonouede Kajitakaichoo towakokuminkararikaisareru

kaigini shite ikitaito, gakujyutsukaigini shite ikitai, sarani, sono tameninani o yarubeki ka to iukotomoisshoniyatteikitai to, maasonoue de, imaInoue Daijin no tokorodesooshitakotonitsuitewagooi o shimashite, ima, Inoue Daijin no tokorode, Kajitakaichoo to kaidan o shite, sooshitakoto o susumesaseteitadaiteirutokoro de arimasu. Ninnmeisuru shinai toiukotowa(pause) sonomama no jyootaininatteimasu. De kekka to shite rironntekiniwaKawachigiin no iutoori datowatashiwaomotteimasu.

(Well, (pause) logically speaking, I fully agree with member Kawachi. When President Kajita came to see me, I indeed received his formal letter, which was about the formal demand to re-elect six members. Based on this, with President Kajita, we discussed how to re-organize the SCJ to be easily recognized by the general public, also we discussed what we need to do as a group. We also discussed what we can do together with Minister Inoue who is in charge of science and technology among others. The question of appointing or not-appointing the six members is still in progress and nothing has been discussed or finalized. To summarize, I fully agree with member Kawachi regarding what he has been discussing. Emphasis added)

Suga's response, in this context, is shocking. The fact that he expressed his full agreement with Kawachi without any dispute or diplomatic explanation is unprecedented. Unlike the former Prime Minister Abe, this honest reply by Suga is quite unique in this congressional context. Suga says "I fully agree with member Kawachi" not only once, but twice, at the beginning and ending of the statement. Interestingly, following the prior statement, Suga adds "watashiwaomottemasu" (I personally believe so). This clearly shows that Suga himself concurred, without anyone else's suggestion or advice.

Suga's behavior during the statement is also quite noteworthy. Although he'd brought his files with him to the answering table, he never looked at any of them. Instead, Suga looked directly at Kawachi and expressed his personal opinion and statement. Typically, a secretary or other official will assist Suga during situations like this in a committee meeting. But no one assisted him at this time in this meeting. 
A secretary or representative did notmake Suga's statement. It was Suga's own answer and nobody else created or adjusted it. He responded directly to Kawachi's question, and accepted Kawachi's solidarity style with full agreement.

In short, Suga's statement was remarkable. He created the statement himself and expressed his opinion straightforwardly in front of the entire committee and the general public, who were watching the event over TV and internet systems. Based on this statement alone, we might expect Suga to move towards re-appointing the six members or resolve the issue in some other manner. However, at the time of this writing, neither of these actions have occurred. Although we note the positive (open) influence of the solidarity style used in this context by Kawachi, the opposition's hoped for result (re-appointment of the six members) has yet to bear fruit.

\section{Negative (closed) aspects of Suga's speech style}

Despite the positive (open) aspects of Suga's speech style mentioned above, we must also note that Suga has exhibited negative (closed) aspects in his speech style as well. Masato Imai, a member of the Constitutional Democratic Party and fierce critic of Suga, has chosen to focus on some of these. At a recent committee meeting, Imai brought with him one of Suga's latest books on politics and social justice. The book, titled Seijka no Kakugo (The Commitment of a Politician), was originally published in 2012. Holding the book in hand, Imai recited what Suga had written regarding the qualities of a good beaurocrat and politician. Let us observe the debate between Imai and Suga from the same House of Representatives Budget Committee meeting on November 2, 2020.In the meeting, Imai refers to the firing of an NHK high ranking employee (NHK is a publicly funded TV and radio organization and its employees, like members of the SCJ, are considered public servants).

(3). Diet member Imai: Denka no hootoo, jinjiken, to iu no gaarimasu.Koko ni NHK no tantookachoo o kootetsu toiuno gaarimasu. Nazekootetsushita ka toiu no ga kaitearimasu. Ronsetsuiin no shitsumonnikotaerunarawakaruga, shitsumonmosareteinai no ni, ichikachoogakattenihatsugensuru no wayuruseinai. Tantookachoo o kaeru, to ittewatashiwatantookachoookaeta.Kobetsujinjiosshatterujyanaidesu ka? Kobetsunojinjikonnanishoosainiosshattemasuyo.Naze hon de iete, gakujyutsukaigi dewaienaindesu ka? Kore akirakanikobetsu no yakunin no,kobetsu no jinji nohanashidesuyo. Kokonikaitearimasu. Ima Osshatteirukoto, machigattemasuyo.

(Your book has one chapter called "personnel rights." In this chapter, you refer to the firing of an NHK section chief. If the section chief had not answered a senior advisor's question, it may make sense, but this person actively made his comment without being asked to speak. You thought this was unprecedented and bad behavior and you, as the Minister in charge of NHK at the time, said, I instantly fired him from the position. As you see, you have actively been involved in "personnel affairs" and have exercised your judgement. You actively discussed [in your book] what we call "personnel affairs." Why are you not able to speak about the "personnel affairs" of the SCJ when you have spoken previously about the "personnel affairs" of NHK? The NHK matters are indeed "personnel affairs." What you are defending makes no sense because you have indeed been involved with and discussed the "personnel affairs" of the NHK organization .emphasis added)

Imai uses Suga's words from Suga's own book to try and contradict Suga's current position. Imai argues that Suga's refusal to discuss "personnel matters" is devoid of logic, and Suga has already discussed such matters in a very similar case and situation previously. Let us observe Suga's reply to Imai's questions.

(4). Prime Minister Suga. Anowatashigasono (pause) yakusho no ningen o kaeta to iu no wa, watashiwa NHK kaikaku o yaru to iuno wa,sengen o shite, daijin o shite itandesu. Sonoseisakunihantai o suru. Iyaa, sore wa moo (pause). Sore to konkai no ninmeiken to wamattakuchigau n jyanaide shoo ka?Iya, iya, (pause) Ninmei o shinai to iudakedesukara.

(Well, when I say I discuss "personnel matters" in a public organization, well, when I say I reorganize the NHK system, I stated it clearly when I was the Minister over the NHK. The person in charge was opposing my plan to reorganize the NHK. Well, that is well. . . that is different from the "personnel affairs" we have been discussing in the SCJ. Well, I do not agree to the appointment of the six members of the SCJ. I simply do not accept the six members.) It appears from Suga's statement that he wants to distinguish the "personnel matters" of the NHK from the "personnel matters" of the SCJ, although both situations concern public employees. In his book, Suga clearly states that he fired the section chief of the NHK. However, he sees that situation as different from his rejection of the six nominees to the SCJ. He has justified his actions in the current case by only stating that the SCJ needs to be "wide and comprehensive" in its organizational structure, a vague explanation. Suga's attempt to distinguish the two situations, the NHK from the SCJ, are tenuous at best. It would be useful if Suga could provide a more easy-to-understand explanation regarding the different nature of each organization, and why, if they both have public employees, he can talk openly about one's "personnel matters," but not openly about the other's. 
To confuse matters more, Suga acknowledges the rights set out in Japan's Constitution, Article 15, which states that "the selection and rejection of public officials is the public's inalienable right." Yet, Suga clearly needs to address his understanding of this "inalienable public right" in the context of selecting and rejecting public employees. In the past, Prime Minister Yasuhiro Nakasone regarded the appointment of members to the SCJ as a "formal appointment" (keishikitekininmei) (May 12, 1983). Suga should also explain what he considers to be a "forma lappointment." Further, according to a report from the major newspaper Asahi Shinbun, Suga, in the November 2, 2020Committee meeting of the Diet, repeatedly said, as many as twelve times in one half hour, "I avoid the rejection process" (procesu no setsumeiwahikaeru) (Asahi Shinbun 2020). Clearly, these conflicting statements need additional legal clarification and political analysis.

Next, let us observe the statements of another Diet member, Kiyomi Tsujimoto, of the Constitutional Democratic Party, made at the same November 2, 2020 meeting. Tsujimoto made reference to a famous animation character in Japan called "Kimetsu no yaiba" (Demon Slayer). (For those unfamiliar with the animation film Demon Slayer: Kimetsu no Yaiba the Movie: Mugen Train, it is a feature length film in Japan which has already become the highest-grossing Japanese film of the year 2020.)

Tsujimoto made the following statement using the animation reference, implying a warning for Suga.

(5). Diet member Tsujimoto. Watashiwananimomachigaenai. Subete no ketteikenwawatashiniari, watashi no iukotowazettai de aru. Omaenikyohisurukenriwanai. Watashiwazettai de aru. Tadashii to ittakotogatadasii no da. Konnaserifuitte run desuyo. Koo naranaiyoonikureguremogochuuiitadaki tai to omoimasu.

("I never make mistakes. All decisions belong to me, and what I say is absolutely correct.You cannot deny my decisions. I am absolutely correct. What I sayis right is what is considered to be right." This is what is said in the "Demon slayer." I humbly ask you not to become a person like this man.)

Using the popular animation character reference, Tsujimoto cautioned Suga not to be bull-headed and over-confident. Nevertheless, the general public may, in fact, consider Suga to possess the characteristics of the Demon slayer. Suga may also view himself this way in some respects; to be a determined, trustworthy and reliable politician, who is able to divorce himself from what the opposition does and thinks.

In the past, when Suga worked as the Chief Cabinet Secretary for seven years under the prior administration, he acted in a way that was easy to understand; a concise and straightforward speaker for the government. In a sense, he was a committed officer and true believer in Prime Minister Abe and his political platform. However, when Suga was elected as Prime Minister to lead Japan, many people were expecting him to continue in his role as the honest and committed politician. But Suga has taken on a different role. He appears to consider himself a true reformer who avoids following precedent. He has pushed for regulatory reform including the creation of a governmental digital agency, and he has called for the reduction of cell phone fees for the general public. He also aims for a decarbonized society by the year 2050.Eachone of these policies alone is quite challenging, but each seems to have a direct benefit for the general public. Consequently, many people in Japan still want to trust that Suga will lead the way to solving these problems.

Nonetheless, we must acknowledge the mixed signals seen in Suga's speech styles. In some cases, he seems very honest and straightforward, as in Kawachi's case of (2), yet in other situations, as in Imai's case of (4), Suga appears to be stubborn and uncooperative, sticking to his own belief system. Does Suga's speech style contain both positive (open) and negative (closed) aspects? Is that typical for other politicians in Japan? Alternatively, if the two aspects are indeed different from each other, how and why are they are different from a linguistic perspective?

\section{Theoretical considerations: "report-talk" vs. "rapport-talk"}

Tannen (1993), a well-respected sociolinguist provides an interesting framework for answering our question. According to Tannen, as humans, we have two types of communication styles. One is called "rapport-talk" and the other is called "report-talk." Specifically, "rapport-talk" is a communication style that promotes social affiliation and emotional connection, while "report-talk" is a style focused on exchanging information with little emotional import. Tannen originally used the idea to focus on the male-female gender talk difference or what we call genderlect, but she also extended the idea to talk about involvement strategies in politics such as those used by the American civil rights activist, Jesse Jackson's speech at the 1988 Democratic National Convention (Tannen 2007). Tannen pointed out that Jackson used various involvement strategies such as repetition, dialogue, details, storytelling and tropes to communicate his ideas and move his audience toward acceptance of them and of him in his speech. In all, according to Tannen, Jackson's speech was an act of personal commitment of total commitment and of emotional identification. 
One important theoretical aspect for our context is the fact that politicians, like many other professions, are interested in "sharing" and expanding their own knowledge with others. This approach emphasizes an emotional connection or shared common ground with the constituents and increases the likelihood of accomplishing political goals and objectives. In other words, focusing on rapport-talk and emphasizing emotion is an effective way for politicians to maximize their spoken language and have an impact on democratic institutions in Japan, as well as in other nations.

Tannen (2007) has highlighted several methods to enhance mutual understanding and involvement in speech, including repetition, dialogue, details, and storytelling, all of which pertain to personal emotions. Remarkably, after further analysis, none of these methods are actively used in Suga's speeches, except to a limited extent, as in his phrase "I agree with member Kawachi," used twice in his reply in (2). Japanese politicians, including Suga, seldom use any of these techniques to connect with their constituents. They frequently fail to communicate ideas in a shared emotive manner and consequently fail to move the audience toward a common joint connection.

In sum, we can say that Suga is very good at "report-talk" in which he concisely and promptly answers in his words without inducing much emotion. By contrast, he is not so talented at "rapport-talk" in which he shows his "personal" emotional feelings (except his reply to member Kawachi as in (2)). What Suga may benefit from is modeling his speech style after the powerful and dramatic force of "rapport-talk" as witnessed in speeches of Jessee Jackson in 1988 (Tannen 2007).

It can be argued that focusing more on listeners and paying attention to the emotional connection of speech (rather than a detached, fact-based, delivery of information), and conducting "rapport-talk" rather than "report-talk" with a sense of "solidarity," are effective ways for Suga, as well as other politicians, to attract and gain support from the general public and the media. It is important to keep in mind that the connection between a politician and his or her constituents and the media, is facilitated, even enabled, by a shared, emotional, interpersonal experience which is exhibited in a listeneroriented speech style.

To improve his approval rating with the general public and media, Suga may need to avoid the typical "report-talk" and expand his skills in "rapport-talk." If Suga incorporates more "rapport-talk" methods, as he has partially shown in (2) in his Diet meeting (i.e., repetition of the same phrase), he is likely to find success in this speech style. Some former Prime Ministers such as Prime Minister Kakuei Tanaka (1972-1974) and Prime Minister Junichiro Koizume (20012006), were quite popular among the general public due to their "rapport-talk" methods, while still using "report-talk" at times. Both of them were very skillful in various involvement strategies to attract voters including methods such as repetition, details, dialogue and story-telling.

\section{Conclusion: Suga and Koizumi}

To conclude our examination and analysis, let us compare Suga's speech style with the speech style of the former Prime Minister Junichiro Koizumi. First, let us observe the dialogue between Diet member, Kazuo Shii, of the Communist Party, and Suga, in a different House of Representative Budget Committee meeting on November 4, 2020. Shii asked Suga to clarify whether the rejection of the six nominees would cause problems for the SCJ.

(6). Diet member Shii.Rokumei o ninmeisuru to gakujyutsukaigi no soogootekifukantekikatsudoonimondai o kitasu no ka, kore kiitendesu.

(Does the appointment of the six nominees create any problem for the SCJ with respect to its systems and general activities? I am asking for your response.)

Shii's question is simple. Is there a problem if we do not appoint the six nominees to the SCJ? Let us observe Suga's reply.

(7). Suga. Kokojin no ninmei no riyuunitsuitewaseifu no kikannishozokusurukoomuin no ninmei deari, tsuujyoo no koomuin no ninmei to dooyoonisonoriyuunitsuitewajinjinikansurukoto de ari, okotaewasashihikaetai to omoimasu.

(About appointing personnel, it relates to government employees. Due to this reason, I cannot respond to you because it is a personnel matter of government employees.)

In essence, Suga said he cannot respond to Shii's question because it relates to "personnel matters" of government employees. Suga was simply rejecting Shii's question without giving any details. No details, repetition or dialogue were involved in Suga's reply. Hence, "rapport-talk was avoided.

Now, let us examine what Prime Minister Koizumi (2001-2006) might have said. Unfortunately, it is impossible to have an identical situation for Koizumi simply because he was the Prime Minister of Japan more than 15 years ago. 
However, for the sake of comparison, let us examine Koizumi's speech during his 2013 visit to Finland (at the time he was no longer the Prime Minister) regarding a nuclear power plant waste site (Koizumi 2013). In his speech, Koizumi discussed his experience as follows.

(8). Former Prime Minister Koizumi. Koo iujyookyoowamettanidesuyo. Shikamosoodainajigyoojyanaidesu ka. Yume no arujigyoojyanaidesu ka. Shizen o shigennisuru. Soo iujigyoo. Sore nisoori no kenryoku o furuukotogadekiru. Konna un no ii soori, inai to omoimasuyo.

(We do not experience the situation [of a nuclear power waste site]like this. In addition, it is a splendid job. It is a job with a dream. Use nature as our power. That is our job. Furthermore, we can use the Prime Minister's power. We have not had a Prime Minister like this.)

In his brief statement, Koizumi used jigyoo (job) three times to emphasize his strong stance against future power plant factories in Japan. His repetition accentuated what he (and possibly the audience) was expected to do. He wanted to generate, stimulate, and motivate the audience to see his world, of jigyoo. In addition, he literally used the word yume (dream) to highlight the job. In essence, it was a job with a dream. In this way, the audience could experience a sense of "empowerment."

Another interesting aspect of Koizumi's statement is he made it as if speaking to the then Prime Minister Abe in a story-telling, dialogue-like fashion. The speech functioned as an important political suggestion or advice for Abe, who was ambiguous regarding nuclear policy. By listening to the speech, the audience generally felt a deep connection to it, and that it represented a clear communication from Koizumi to Abe regarding a new proposed nuclear power plant policy for Japan. In other words, the speech was a realistic and proactive form of story-telling for a future Japanese policy in the form of dialogue from Koizumi to Abe. Koizumi was speaking to the audience in a form of a soliloquy as a single speaker. However, he was actually speaking to Abe (as well as the audience) using the conversational skill of story-telling and dialogue.(Tannen 2007).

Koizumi's 2013 speech in Finland is a powerful and energetic example of his "rapport-talk" and his strong and emotional connection with his audiences. It would be a challenge for any politician to obtain and maintain the same sense of conversational involvement which Koizumi seemed to master.

In the present context of the six nominee rejections of the Suga controversy, another prominent Japanese magazine, Shuukan Bunshun, has argued that no political aides on Suga's side can provide any positive solutions to solve the issue (Shuukan Bunshun 2020). Yet, Tokyo Shinbun, a Tokyo newspaper, opined that one solution could be found if politicians simply connected with their listeners, their voters. Quoting the late French president Giscard d' Estaing (1974-1981), the newspaper stated that "the best way to attract voters is to pay close attention to every single listener in order to receive his/her support and eventually the speaker himself will also receive his support from the listeners." (Tokyo Shinbun 2020). The present study would add such encouragement, urging Suga to incorporate and maintain a "rapport-talk" speech style (in addition to his "report-talk" speech style) in order to navigate this and other issues that will arise during his term as the new Prime Minister. By connecting with his listeners, In this way, he just may succeed as an effective, competent and talented politician in Japan and the world.

\section{Acknowledgement}

I am grateful to Robert Wood for his valuable suggestions. Needless to say, all shortcomings are mine.

\section{References}

Asahi Shinbun. 2020. Suga Seiken no "Toobenhikaeru," haya 80 kai. November 9, 2020.

https://digital.asahi.com/articles/ASNC97FQ0NC9UTFK009.html?iref=pc_rellink_03

Feldman, O. 2000. Non-oratorical discourse and political humor in Japan: Editorial cartoons, satire, and attitudes toward authority. Beyond public speech and symbols. ed. by C. Landtsheer and O. Feldman, 165-191. London: Traeger.

Ikeda, K. 2009. Audience participation through interjection. Journal of Language and Politics. 52-71.

Koizumi, J. 2013. Genpatsusokuji zero. Tokyo: Nihon Kisha Club. https://jp.reuters.com/article/t9n0ex01j-koizumi-nuclear-idJPTYE9AB03N20131112

KokkaiKaigirokuKensaku System. 2020. https://kokkai.ndl.go.jp/\#/

Kyodo News. 2020. Shijisuru, 66.4\%. September 18, 2020.

https://jp.sputniknews.com/japan/202009187780463/

Maynard, S. 1994. Images of involvement and integrity:Rhetorical styles of a Japanese politician. Discourse and Society. 233-261. 
Nihon Keizai Shinbun. 2020. KanryuuTooben.November 7, 2020.

https://gogotamu2019.blog.fc2.com/blog-entry-17367.html

ShibunAkahata. 2020. Shushoo no ninmeiwa "keishikiteki." October 5, 2020.

https://www.jcp.or.jp/akahata/aik20/2020-10-05/2020100501_01_1.html

ShuukanBunshun. 2020. Sugashushoowadokodenani o machigatta no ka (Where did Prime Minister Suga make mistakes?). Tokyo: BungeiShunjyu. November 27, 2020.

https://news.yahoo.co.jp/articles/9af6f36648a81bdc4ea14655ee07eef9b4c30e2f?page=1

Suga, Y. 2012. Seijika no kakugo (Commitment of a politician). Tokyo: BungeiShunjyuu.

Tannen, D. 1993. Framing in discourse. New York: Oxford University Press.

Tannen, D. 2007. Talking voices: Repetition, dialogue, and imagery in conversational discourse.Cambridge: Cambridge University Press.

Tokyo Shinbun. 2020. Fude aria. December 6, 2020.

https://www.tokyo-np.co.jp/article/72715?rct=hissen

The Mainichi. 2020. Editorial: Summon deputy Cabinet secretary to Japan Diet over science council rejections. November 6, 2020. https://mainichi.jp/english/articles/20201106/p2a/00m/0na/047000c

University World News. 2020. PM blocks nominations of six academics to Science Council.

October 8, 2020.https://www.universityworldnews.com/post.php?story=20201008203901785 